\title{
The Implementation of the Safekeeping Agreement (Consignment) In Supermarket
}

\section{Fitriaji Wira Nursasongko*) and Umar Ma'ruf**)}

*) Faculty of Law, Universitas Islam Sultan Agung (UNISSULA) Semarang, E-mail: sasongkoa00@gmail.com

**) Faculty of Law, Universitas Islam Sultan Agung (UNISSULA) Semarang

\begin{abstract}
.
Along with the times, the economy in the current era is diverse and growing very rapidly, especially in the business world. Many business activities require cooperation from other business actors with the aim of developing business potential, businesses between these business actors are usually based on trust between parties as the main basis for building businesses that can mutually benefit each other. One of the cooperation agreements is the safekeeping of goods (consignment). In practice, the goods custody agreement (consignment) requires good cooperation and the goods sold must be of good quality in accordance with the provisions contained in the Kedungmundu Style Supermarket. This study aims to find out the procedures and implementation of the consignment agreement at the Gaya Kedungmundu Supermarket, Semarang, to find out the problems or obstacles that exist in the implementation of the consignment agreement at the Kedungmundu Supermarket Semarang in the event of a default between the two parties. The method used in this study is a sociological juridical approach, which is carried out by using an approach using the assistance of other social sciences, through this approach it means that in the study of the data it is not only guided by juridical aspects. But by looking at the reality in practice. The specification of the research conducted is descriptive analysis. This research analyzes and presents facts systematically so that it can be easier to understand and conclude. Based on this research, it can be concluded that the procedure for implementing a consignment agreement at the Gaya Kedungmundu Supermarket, Semarang, starting from filling out the stages to be able to cooperate in a consignment relationship, requires an agreement and there is no coercion from other parties according to Article 1320 of the Civil Code. in the implementation of the goods safekeeping agreement (consignment) which includes internal and external obstacles. Efforts to complete the implementation of the goods safekeeping agreement (consignment) include litigation and non-litigation, for example through legal channels and deliberation or negotiation.
\end{abstract}

Keywords: Agreement Consignment; Implementation.

\section{Introduction}

The economy in this era is very diverse and fast, especially in the business world. Business actors carry out their activities or ways of doing business with various ideas to attract consumers to be interested and buy the products sold by business actors. Many business activities require cooperation from other business actors with the aim of developing business potential, businesses between these business actors are usually based on trust between parties as the main basis for building mutually beneficial business relationships. Conducting business relationship activities at this time is not only based on trust, business actors need tangible evidence in business relationship activities and a written agreement which is one of the methods that can be used by business actors in conducting a 
business cooperation relationship. One of the programs currently in use is that MSME business actors can leave their merchandise in one place and collaborate with mutual benefits for both parties.

One of the factors influencing the development of treaty law in Indonesia is developments in the trade sector. The variety of transactions in trade gives rise to various agreements made by MSME business actors as well as suppliers and parties from place providers. The agreement arises as a manifestation of the existence of transactions between MSME business actors as well as suppliers and place providers, namely Gaya supermarkets.

As it is known that the articles in the contract law as regulated in book III of the Civil Code can be removed, the party making the agreement. However, there is still a need for a guideline in treaty law in Indonesia. ${ }^{1}$

According to article 1338 paragraph (1) of the Civil Code, all agreements made legally apply as law for those who make them. Referring to the article above, it can be seen that the contract law in Indonesia also adheres to the principle of freedom of contract. Based on the principle of freedom of contract, the parties are free to determine the method, form and content of the agreement. The parties are also free to decide whether or not to make an agreement and are free to choose with whom they will make an agreement. The agreement binds the parties as befits a law2.

Custody of goods occurs when a person receives an item from another person, on the condition that he will keep it and return it in its original form. This is the definition provided by Article 1694 BW regarding the custody agreement. According to the law there are two kinds of true custody and secretory. The true safekeeping of goods is considered to be made free of charge, if not agreed otherwise, while it can only affect movable goods (article 1696). The agreement has not been carried out other than with the surrender of the goods in earnest or presumptively (article 1697). This provision illustrates again the real nature of the custody agreement, which is different from the nature of other agreements in general which are sensual. ${ }^{3}$

Supermarket Gaya provides a place for producers so that the results of factory production or the results of individual work or are called Micro, Small, Medium Enterprises (SMEs). In Indonesia, Micro, Small and Medium Enterprises (MSMEs) are often abbreviated as MSMEs, MSMEs are currently considered an effective means of poverty alleviation. From statistics and research conducted, MSMEs represent the largest number of business groups. MSMEs have been legally regulated through Law Number 20 of 2008 concerning Micro, Small and Medium Enterprises. MSMEs are the largest group of economic actors in the Indonesian economy and have proven to be a safety valve for the national economy in times of crisis, as well as being a dynamist of economic growth after the economic crisis. In

\footnotetext{
${ }^{1}$ M. Yahya Harahap, 1986, Segi-Segi Hukum Perjanjian, Bandung: Alumni, p. 76 and Mariam Darus Badrulzaman, Sutan Remy Sjahdeini, Heru Soepraptomo Faturrahman Djamil, and Taryana Soenandar, 2001, Kompilasi Hukum Perikatan, Jakarta: Citra Aditya Bakti, p.vi

2 Chuasanga A., Ong Argo Victoria, "Legal Principles Under Criminal Law in Indonesia and Thailand", Jurnal Daulat Hukum, Vol 2, No 1 (2019) http://jurnal.unissula.ac.id/index.php/RH/article/view/4218 ${ }^{3}$ M.Yahya Harahap, Op.cit, p. 107.
} 
addition to being the business sector with the largest contribution to national development, ${ }^{4}$

MSME actors certainly leave their goods at Gaya supermarkets so that the results of their work can be traded through style supermarkets and make a profit by working smart. The practice of selling consignment (consignment) is still common in our society, and is one of the business schemes that has its own advantages compared to break-up. Buy and drop is an ordinary sales scheme, where the buyer (buyer, or customer) buys merchandise from the seller (us as the seller, or the company) and all risks related to the goods are transferred to the buyer. Whether sales are made by cash or credit, another term for credit sales is 'on account'. 5

Company suppliers and MSME actors are interested in entrusting their goods at Gaya Supermarket which is one of the shopping places in the city of Semarang. Gaya supermarket itself is also in a very strategic position, which is near a densely populated community environment, which incidentally shopping is a very necessary requirement for the community around Gaya supermarket.

Some businesses that usually use a deposit sales scheme are as follows: Entrusted food products sell in supermarkets; Entrusted food products are sold in stalls (eg bread and cakes); Daily or weekly newspaper and magazine products at delivery men or newsagents; Books by publishers in bookstores or outlets; and Drugs at the pharmacy.

Goods storage agreements (consignment) like this can also maximize the sale of goods or products owned by MSME business actors or companies that work together with the place provider. A consignment is an agreement in which one of the parties who owns the goods submits a number of goods to a certain party for sale at the price and terms stipulated in the agreement. The party who delivers the goods (the owner) is called the consignor/safety. The party who receives the goods on the consignment is called the consignee/consigner/commissioner. For the consignor, goods that are entrusted to the consignee for sale are called consignment goods (consignment out).

- The elements in the consignment agreement are: There is an agreement ; The existence of the owner of the goods; There is a party entrusted with goods; There are items that are deposited; There are terms of sale; There is a commission

- There are 4 things that are characteristic of a Consignment transaction, namely: Consigned goods must be reported as inventory by the Consignor, because the rights to the goods are still with the Consignor; Consignment delivery of goods does not generate income for the Consignor and vice versa; The Consignor is responsible for all costs associated with consigned goods unless otherwise specified; The Commissioner within the limits of his ability is obliged to maintain the security and safety of the commission items he receives.

The sales system with the consignment system does have differences from the sales system in general. If we look at supermarkets, they sell various kinds of products with various variants and in large quantities. If there is no agreement in

${ }^{4} \underline{\text { https://endah240395.wordpress.com/2015/01/05/makalah-umkm/accessed June 30, } 2019}$ 
written form and definitely binds both parties in a consignment cooperation agreement, in the event of a dispute between the two parties it will be difficult to take legal actions in the event of a dispute, due to the absence of a definite legal relationship between the cooperation agreement in written form, although there has been an element of reciprocal agreement or an agreement agreed upon by both parties.

In general, before the goods are delivered on consignment a complete written agreement between the consignor and the consignee is made to avoid disputes in the future. ${ }^{6}$

\section{Research Methods}

The approach method used in this research is the juridical-sociological research method, meaning that in reviewing a problem it is not only viewed from the juridical point of view in the legislation, but is also carried out through field research in order to obtain primary data, so that the authors can see the operation of law in society. Juridical factors are legal norms/regulations relating to agrarian law and civil law. The sociological factor is the symptoms that arise in the community and then studied and analyzed based on the existing laws and regulations.

Basically this research is a combination of library research and field research. This specification is descriptive analysis, namely research that does not only describe the state of the object but provides an overview of the problems that occur. (Soemitro, 1992) Especially in this case regarding issues related to the implementation of a consignment agreement at a Kedungmundu-style supermarket in Semarang. Primary data Primary data is data obtained directly from the field so as to obtain official/authentic data from the Kedungmundu-style supermarket in Semarang. Secondary Data; Secondary data, namely Primary Legal Material, Secondary Legal Material, Tertiary Law Material. In this research data collection efforts there are several techniques used, which include: Library research , Document Study and Interview. After all the data obtained is collected, it will then be reviewed and analyzed qualitatively by studying all the answers. Data analysis is carried out with the aim of simplifying the processed data so that it is easy to read and understand

\section{Results and Discussion}

\subsection{Implementation of the Goods Deposit Agreement (Consignment) at the Kedungmundu Style Supermarket, Semarang}

Place providers have a very important role in the economy of MSME business actors. Place providers, apart from supporting the smooth running of the community's economic activities by providing place facilities, are also the organizers of buying and selling transactions between consumers and producers, ${ }^{6}$ Nurdin Usman, (2002), Konteks Implementasi Berbasis Kurikulum, Jakarta: Raja Grafindo Persada
and Prof.R.Subekti, S.H., (1987), Hukum Perjanjian, Jakarta: Citra Aditya Bhakti 
both locally and nationally. The smooth running of this place provider business can increase public confidence in the quality and quality of the goods traded.

Basically, the good name of a shopping place in the community is the quality of the goods traded, and balanced with affordable prices for the lower middle class economy, so that there can be a stable economic turnover in a shopping place. From those who shop from the upper middle class to the lower middle class, they can shop at this place for their daily needs.

Price has an important role in marketing a product so that it can be accepted by consumers. Price is the payment for goods and services that not only includes the basic cost, but also includes additional costs such as discounts or delays in payment. This confirms that each seller is "free" to set his own selling price.

For this reason, the company implements several price policies to encourage consumer willingness, so that consumers are interested in buying marketed goods, because price is one of the determinants of marketing success. The price policy that the company can do is to provide a cash discount 7 .

The strategy of giving cash discounts carried out by companies and distributions is intended to attract consumers to sell products. With so many consumers buying consigned goods, there will also be many benefits that will be obtained by both parties. Because in this consignment agreement, the profits obtained by the consignee depend on the number of sales of consigned goods or not.

The economy in the current era also implements an economic system for storing goods that will be traded (consigned) which involves companies such as Indofood and Gaya Supermarkets. Supermarket Gaya also accepts goods storage (consignment) for MSME actors who wish to entrust their merchandise at Gaya Supermarket with certain conditions.

\subsection{Settlement If Problems Occur in Safekeeping of Goods (Consignment) between Suppliers and Gaya Supermarkets}

The goods storage agreement (consignment) is an agreement between the two parties, namely the management of the Gaya Supermarket and the supplier who entrusts the goods to be traded in the Gaya Supermarket. Achievement or what in English is also referred to as "performance" in contract law is intended as an implementation of the things written in a contract by the party who has bound themselves to it, the implementation of which is in accordance with the "terms" and "conditions" as mentioned. in the contract concerned

The models and achievements are as stated in Article 1234 of the Civil Code, namely in the form of: 1 . give something, 2. do something, and 3. do nothing.

In society, as previously known, there are written and unwritten contracts, a written contract is an agreement in which a party and another party bind themselves and promise to perform an achievement that is outlined in the form of a written contract, this is called a written contract, while an unwritten contract is

\footnotetext{
7 Muhammad siddiq armia. 2017. "Hubungan Ideal Partai Politik Dalam Pengisian Jabatan Publik." Jurnal Review Politik 07(1): 126-46, see too Praptini, Sri, Sri Kusriyah, and Aryani Witasari. 2019. "Constitution and Constitutionalism of Indonesia." Jurnal Daulat Hukum 2(1): 7-14.
} 
an agreement or agreement between two or more legal subjects who agree to perform each other's achievements orally or without writing (only from speech)

\section{Clossing}

The implementation of the goods storage agreement (consignment) at the Gaya Kedungmundu supermarket is one means for suppliers to market their goods more easily and be better known in the community. Goods that can be included in Gaya Supermarkets are also considered if they are needed in various circles of society or not and can be continuously sold at Gaya Supermarkets so that people who shop can feel satisfied when shopping. The rights and obligations of the management of Swalayan Gaya with suppliers can also be legally accounted for. The Kedungmundu Style supermarket in Semarang is an example of a supermarket with good management. Obstacles in the implementation of the goods custody agreement ( consignment) almost $90 \%$ do not have problems in implementing the consignment agreement. Therefore, Supermarket Gaya as a supplier's goal to cooperate in the consignment system because it has good management and is always disciplined in providing obligations from suppliers.

\section{References}

\section{Journals:}

[1] Alvat, Andi Pradikta. 2019. "Politics Of Law Human Rights Protection In Indonesia." Jurnal Daulat Hukum 2(4): 513-20.

[2] Chuasanga A., Ong Argo Victoria. (2019). Legal Principles Under Criminal Law in Indonesia and Thailand, Jurnal Daulat Hukum, Vol 2, No 1 (2019) http://jurnal.unissula.ac.id/index.php/RH/article/view/4218

[3] Muhammad siddiq armia. 2017. "Hubungan Ideal Partai Politik Dalam Pengisian Jabatan Publik." Jurnal Review Politik 07(1): 126-46.

[4] Praptini, Sri, Sri Kusriyah, and Aryani Witasari. 2019. "Constitution and Constitutionalism of Indonesia." Jurnal Daulat Hukum 2(1): 7-14.

\section{Books:}

[1] Mariam Darus Badrulzaman, Sutan Remy Sjahdeini, Heru Soepraptomo Faturrahman Djamil, and Taryana Soenandar, 2001, Kompilasi Hukum Perikatan, Jakarta: Citra Aditya Bakti

[2] M. Yahya Harahap, 1986, Segi-Segi Hukum Perjanjian, Bandung: Alumni

[3] Nurdin Usman, 2002, Konteks Implementasi Berbasis Kurikulum, Jakarta: Raja Grafindo Persada

[4] R.Subekti, 1987, Hukum Perjanjian, Jakarta: Citra Aditya Bhakti

\section{Regulation:}

[1] Act No. 8 of 1999 concerning Consumer Protection

[2] Regulation of the Minister of Trade No.11/M-DAG/PER/3/2006 concerning Provisions and Procedures for Issuing Registration Certificates for Agents or Distributors of Goods and/or Services("Permendag No. 11/2006")

\section{Internet:}


[1] Diana Kusumasari, Perbedaan Batasan Usia Cakap Hukum dalam Peraturan Perundang-Undangan, http://www.hukumonline.com/klinik/detail/lt4eec5db1d36b7/perbedaanbatasan-usia-cakap-hukum-dalam-peraturan-perundang-undangan

[2] https//kbbi.web.id/toko.

[3] https://endah240395.wordpress.com/2015/01/05/makalah-umkm/

[4] https://zahiraccounting.com/id/blog/memahami-apa-itu-konsinyasi/ 